\title{
A State-of-the-Art Review on the Evolving Utility of Endoscopic Ultrasound in Liver Diseases Diagnosis
}

\author{
Wisam Sbeit ${ }^{1,2}$, Anas Kadah ${ }^{1,2}$, Mahmud Mahamid ${ }^{3}$, Rinaldo Pellicano ${ }^{4}\left(\right.$, Amir Mari ${ }^{2,5}$ and \\ Tawfik Khoury 1,2,5,*iD \\ 1 Department of Gastroenterology, Galilee Medical Center, Nahariya 22100, Israel; wisams@gmc.gov.il (W.S.); \\ anas18kadah@msn.com (A.K.) \\ 2 Faculty of Medicine in the Galilee, Bar-Ilan University, Safed 1311502, Israel \\ 3 Department of Gastroenterology, Sharee Zedek Medical Center, Jerusalem 9103102, Israel; \\ mahmudmahamid@yahoo.com \\ 4 Gastroenterology Unit, Molinette Hospital, 10126 Turin, Italy; rinaldo_pellican@hotmail.com \\ 5 Gastroenterology and Endoscopy Units, The Nazareth Hospital, EMMS, Nazareth 16100, Israel; \\ amir.mari@hotmail.com \\ * Correspondence: tawfikkhoury1@hotmail.com; Tel.: +972-509870611
}

Received: 6 July 2020; Accepted: 21 July 2020; Published: 23 July 2020

\begin{abstract}
Liver diseases are amongst the most common diseases worldwide and manifest as a parenchymatic and/or biliary injury due to several causes as well as focal liver lesions, ranging from benign to malignant ones. The diagnosis of liver diseases is based mainly on biochemical and advanced imaging studies and, when required, on liver biopsy. Endoscopic ultrasound (EUS), which combines endoscopy and ultrasonography, is one of the main examination techniques used in gastroenterology as it is applied to evaluate abnormalities in the lumen of the upper and lower gastrointestinal tract and to define pancreatic and hepato-biliary features, often in chronic patients. Given its high spatial resolution and its proximity to the liver, EUS is gaining popularity in the diagnostic work up of liver diseases. This is a comprehensive overview of the current literature on the diagnostic indications for EUS use in patients with liver diseases. We performed a MEDLINE $\backslash$ PubMed and Embase search, and all articles that were relevant, after reviewing abstracts, were assessed and the full text was analyzed to extract data regarding technical success, diagnostic yield, bioptic characteristics, and complications rate. EUS-guided imaging and biopsy techniques in liver diseases have shown consistent favorable promising results among the reports through the literature, with an excellent diagnostic yield and safety profile, especially in the context of focal lesions and portal hypertension. The application of EUS in the diagnosis of liver diseases is a promising technique and should be considered as a first-line therapeutic option in selected cases.
\end{abstract}

Keywords: EUS; endoscopic ultrasonography; liver diseases; diagnosis

\section{Introduction}

Since its first introduction in the 1980s [1], the applications of endoscopic ultrasound (EUS) are expanding quickly, due to its high spatial resolution to cover almost every field in gastroenterology, in addition to cardiac, renal, and the respiratory tract [2]. These diverse diagnostic and therapeutic applications have become feasible, taking advantage of the unique property of EUS, which combines endoscopy and ultrasonography (US). In recent years, an expanding volume of reports, describing the use of EUS as a complementary diagnostic tool in some contexts of liver diseases, has been published. In this review, we summarized the current data on EUS applications in hepatology. 


\section{Methods}

A search for studies published before 30 March 2020 was performed using the Medline/PubMed and Embase databases inputting the keywords "EUS" or "endoscopic ultrasound" and any of the following: "liver" or "hepatic", "portal hypertension", "focal lesions", "gastric" or "esophageal varices", "cirrhosis", "biopsy", "fine needle aspiration", "fine needle biopsy", and "liver diseases". Overall, we screened 48 papers; of them, 19 articles were excluded as they were review articles. The remaining 29 articles were included in the final analysis. The search was restricted to articles published in the English language.

\section{Advantages of Endoscopic Ultrasound (EUS) in Evaluating Liver Diseases}

There are several advantages of EUS compared to conventional images obtained by US and computed tomography (CT). The most important advantage is the proximity of the EUS transducer to the liver, and the ability to identify intervening structures and blood vessels [3]. Together with its low rate of adverse events, EUS constitutes a highly suitable modality for diagnosis and staging of primary malignant tumors and metastatic liver diseases [4]. The second advantage is the possibility to combine its images with those of the novel real-time elastography (RTE) that provide semi-quantitative measurements of liver parenchyma and focal lesion stiffness as documented by color images [5]. The third one is due to the fact that new-generation echoendoscopes are equipped with color, power, and pulsed Doppler, allowing identification of blood vessels, and evaluating portal hypertension, collateral vessels in portal hypertension, and intervening vessels during puncture [5,6]. The fourth one is the ability to obtain contrast-enhancement (CE) images, which improve the diagnostic performance in the case of focal lesions [7]. The last one is the ability to perform EUS-guided liver biopsy, which seems to be safer than the percutaneous route of biopsy, especially in patients with liver cirrhosis ant its accompanying coagulation disorder [8].

Hence, the additive value of EUS in the management of liver diseases is derived mainly from the enhanced imaging quality and the biopsy acquisition ability.

\section{EUS-Guided Imaging Diagnosis of Liver Diseases}

\subsection{EUS-Guided Imaging in Chronic Liver Diseases/Cirrhosis}

According to the European Association for the Study of the Liver (EASL) clinical practice guidelines, liver biopsy is the gold standard diagnostic test for cirrhosis, but as it is not without drawbacks, including its invasive nature, cost, complications, and sampling errors, several noninvasive tests based on tissue stiffness, such as US elastography, have emerged as a substitute avoiding these drawbacks [9]. This procedure has the advantage of demonstrating a liver parenchyma volume of about 100 times greater than that obtained by biopsy, and thus it is potentially less amenable to sampling error [10]. Noninvasive fibrosis markers, such as liver stiffness measurements (transient elastography (TE), Fibroscan, and RTE), have the ability to diagnose the liver fibrosis degree [11]. However, the performance of these tests by the transabdominal approach is suboptimal, especially in the case of obese patients and in those with ascites [9]. In these cases, EUS-guided liver stiffness assessment is advantageous and more efficacious, given the proximity of the transducer to the liver, thus avoiding the abdominal wall fat and interposed abdominal gas. Thus, EUS may serve as a more accurate test for liver fibrosis as measured by RTE [12]. By the proximity of the EUS transducer to the liver, EUS RTE is supposed to be more sensitive than transabdominal RTE in determining the liver fibrosis degree, due to the thinner gastric wall compared to abdominal the wall, which the signal has to penetrate [13]. The liver fibrosis index (LFI), calculated from RTE images, was shown to be correlated with advanced fibrosis according to the METAVIR score in chronic hepatitis C [14]. Based on the same principle, LFI obtained from EUS-RTE images was also shown to have a significant correlation with abdominal imaging and could discriminate between normal, fatty, and cirrhotic-appearing livers, and thus might be an adjunct tool in chronic liver disease investigation [13]. Transabdominal US elastography is the 
procedure of choice in assessing liver fibrosis, due to its ease of use, availability, low cost, and high safety profile. However, as most chronic liver disease patients will undergo upper endoscopy for variceal screening or follow up, and as in cases of liver enzymes abnormalities, investigation by EUS to rule out pancreato-biliary pathology will be performed, and the liver parenchyma may be evaluated by EUS elastography in the same session. A recent study by Tu et al. evaluated the accuracy of EUS, EUS-fibroscan, acoustic radiation force impulse, aspartate aminotransferase-to-platelet ratio, and their combination to detect varices. The authors included 322 patients with chronic viral liver disease and who were divided into an early cirrhosis group (Child-Pugh A grade) vs. a chronic hepatitis group based on clinical diagnosis. The authors reached the conclusion that these modalities had a significantly high detection rate in patients with early stage liver cirrhosis than in those with chronic hepatitis [15]. This finding underscores the emerging and promising role of EUS including fibroscan in reaching an early diagnosis of liver cirrhosis among patients with chronic hepatitis. Further studies are necessary to confirm the available data and to compare the other non-invasive fibrosis tools with EUS-based examination.

\subsection{EUS-Guided Imaging in Focal Liver Lesions}

Most focal liver lesions are incidentally diagnosed by US, CT, or magnetic resonance imaging (MRI) while sometimes these are discovered during surveillance of patients with high risk for hepatic malignancy or during a preoperative staging of malignancies. Elucidating the exact nature of these focal lesions is of tremendous significance as this may influence the management, stage, and prognosis [4]. Moreover, the traditional imaging studies may underestimate the diagnosis of small hepatic lesions. The diagnostic accuracy of EUS in detecting small hepatic lesions mostly less than $1 \mathrm{~cm}$ exceeds that of radiological examinations by US, CT, and MRI [4,16], and it may be used to detect suspicious small hepatic metastasis in the setting of other primary malignancies. To date, only few studies have assessed the additional benefit of traditional EUS over the other imaging tools for hepatic metastasis. An article by Awad et al. reported that EUS identified $28 \%$ of new additional hepatic lesions among 14 patients who were suspected to have hepatic metastasis by CT [17]. Moreover, another study addressed the diagnostic yield of EUS vs. CT in the detection of liver metastasis among patients with a newly confirmed diagnosis of pulmonary, pancreato-biliary, gastro-esophageal, and colonic malignancies. The diagnostic accuracies of EUS and CT scan for hepatic lesions were $98 \%$ and $92 \%$, respectively $(p=0.05)$. Additionally, EUS detected a significantly higher number of metastatic lesions in the liver compared to CT (40 vs. 19, respectively; $p=0.008$ ) [18]. Moreover, the advent of EUS elastography, which is the first non-invasive tool introduced to quantify the stiffness of liver tissue and liver masses [19], and its significant ability to distinguish between malignant and benign focal liver lesions, as the former are much more stiffer than the latter [20], has rendered available an additive tool to improve the EUS ability in the characterization of liver masses (Figure 1). For example, malignant liver masses are about 100-fold harder and stiffer than the surrounding normal tissue [20]. Furthermore, Saldolescu et al. demonstrated that benign lesions have significantly lower stiffness values than neoplastic lesions (hepatocellular carcinoma (HCC), cholangiocarcinoma, and metastases). The authors defined a hue histogram cut-off value of 170 , which was able to discriminate between benign and malignant tumors with a $92.5 \%$ sensitivity, $88.8 \%$ specificity, $88.6 \%$ accuracy, $86.7 \%$ positive predictive value, and $92.3 \%$ negative predictive value [21]. Additionally, using ultrasound contrast agents (UCAs) either under Doppler by contrast-enhanced-EUS (CE-EUS) [22], or contrast harmonic-EUS (CH-EUS), the microvascular architecture could be visualized, allowing a better detection and characterization of focal lesions [22]. Taking advantage of the dual liver blood supply by the portal vein and hepatic artery, $\mathrm{CH}$-EUS examination of the liver is divided into the arterial phase lasting up to $30 \mathrm{~s}$ from injection, during which enhancement increases progressively, the portal phase lasting from 30-120 s, and the venous phase thereafter [23]. The CE-EUS appearance of liver metastasis during the arterial phase shows variable contrast enhancements as they are mostly peripheral and weak hyper-enhance lesions. While, in the delay portal phase, the liver metastasis is demonstrated as dark hypo-vascular 
lesions. During both arterial and portal phases, hypo-enhancement is pathognomonic to all metastases, regardless of eventual enhancement in the arterial phase because the liver tissue retains the UCA, while the metastases present a rapid and marked "washout" [24].

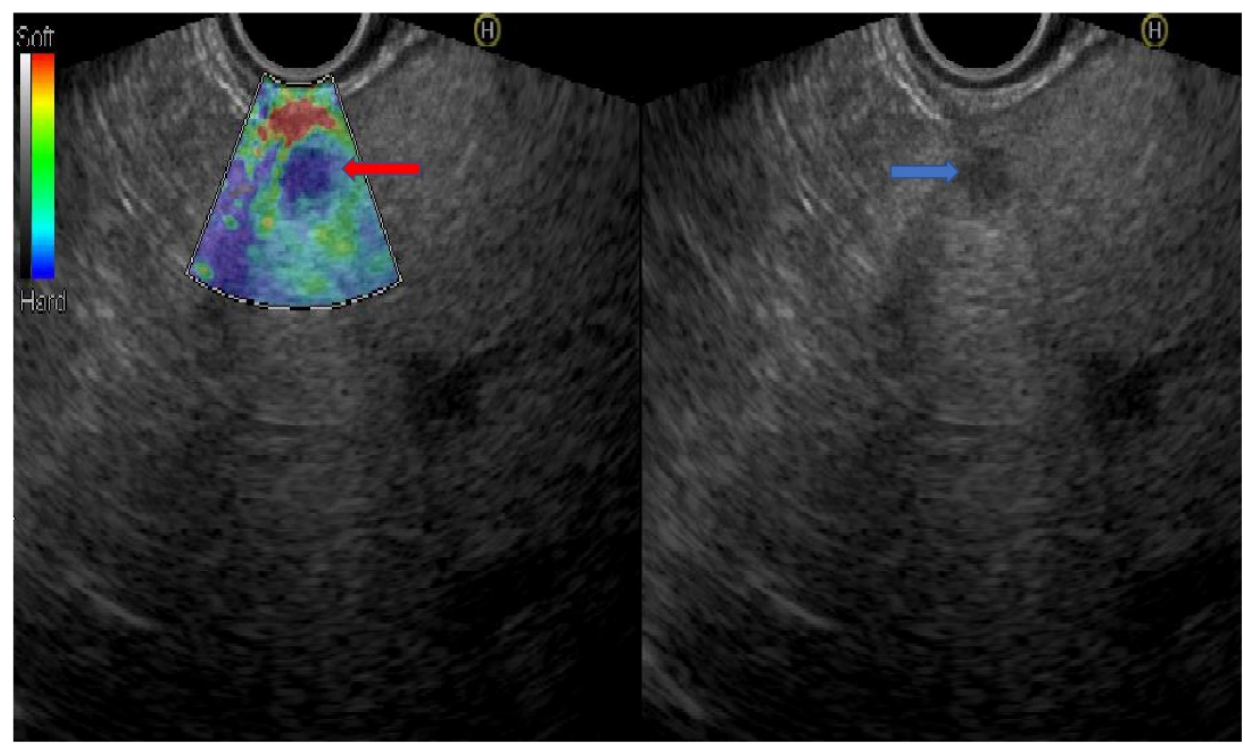

Figure 1. A patient with metastatic pancreatic adenocarcinoma to the liver. The blue arrow shows the liver metastasis by linear echoendoscope. The red arrow shows the lesion by real-time EUS-elastography in a blue color reflecting the hardness and stiffness of the lesion (the picture was supplied from the gastroenterology department at Galilee Medical Center).

A study by $\mathrm{O}$ et al. reported the additional usefulness of CH-EUS, over traditional EUS, to characterize suspected hepatic lesions in 30 patients. Before CE, 22 out of 30 patients $(73.3 \%)$ were identified on traditional EUS. This number increased to 28 out of 30 patients $(93.3 \%)$ after $\mathrm{CE}$, with a $100 \%$ technical success and no procedure-related adverse events [25]. Thus, although data regarding the application of traditional EUS and CE-EUS are still accumulating, there is a promising benefit of introducing this diagnostic tool into the daily clinical practice in suspected cases to maximize the patient's management. Further large prospective studies are warranted to confirm the aforementioned findings.

\subsection{EUS-Guided Portal Pressure Measurement}

The portal vein (PV) carries about $1500 \mathrm{~mL} / \mathrm{min}$ of blood to the liver. Any increased resistance to flow may lead to portal hypertension. An increase in portal pressure induces the development of portosystemic collateral circulation with compensatory shunting, resulting in several disturbances, such as gastroesophageal varices. Cirrhosis, the end stage of any chronic liver disease, is the most important cause of portal hypertension. Since in patients with portal hypertension, prevention and therapy of the major complications, such as bleeding from gastroesophageal varices, are mandatory, the diagnosis of this condition represents a crucial step in hepatology. Portal pressure measurement can be accessed by two techniques. The first is by applying TE, which has also been shown to be an effective modality in evaluating portal hypertension. In asymptomatic patients with chronic liver disease, early portal hypertension could be detected by routine clinical data and TE [26]. A study, including patients with hepatitis $C$ recurrence after liver transplantation showed that liver stiffness, as measured by TE, reflected with high sensitivity and specificity portal hypertension [27]. The second one is by performing direct measurement of portal pressure. In fact, EUS enjoys a high spatial resolution of blood vessels, thus allowing vascular interventions to be carried out, with the PV being the most attractive, especially in light of difficult standard percutaneous access [28]. This direct measurement aims to estimate the portal pressure gradient (PPG) by using a 25-gauge needle that is inserted into the PV and 
the hepatic vein (HV) or inferior vena cava (IVC), if HV is difficult to access, to estimate the direct pressure of both veins; then, PPG is derived by subtracting the HV pressure from the PV pressure. To date, only two human studies have been published on the utility of EUS-guided portal pressure measurement (Table 1). This technique was firstly reported by Fujii et al., who described a patient with recurrent gastrointestinal bleeding with PPG of $1 \mathrm{~mm} \mathrm{Hg}$ without mention of procedure-related complications 4 days later [29]. An animal study, on swine, showed the effectiveness of this technique with excellent accuracy in estimating portal hypertension as it showed a strong correlation with the criterion standard of trans-jugular wedged and free HV pressure measurements by interventional radiology [30]. The second study, on humans, was performed by Huang et al., who reported 28 patients who underwent PPG measurement techniques with a complete technical success rate without adverse events; therefore, the procedure appears safe even in patients with portal hypertension [31]. Despite these encouraging data, prospective multicenter studies are needed to validate such results, before adopting this approach in the clinical setting.

Table 1. Human studies reporting the utility of EUS-guided portal hypertension measurement.

\begin{tabular}{ccccccc}
\hline Reference & Patients No. & $\begin{array}{c}\text { Technical } \\
\text { Success, } \%\end{array}$ & $\begin{array}{c}\text { Diagnostic } \\
\text { Yield, } \%\end{array}$ & $\begin{array}{c}\text { Needle } \\
\text { Used }\end{array}$ & $\begin{array}{c}\text { PPG mm Hg } \\
\text { (Mean, Range) }\end{array}$ & $\begin{array}{c}\text { Complications, } \\
\text { N (\%) }\end{array}$ \\
\hline $\begin{array}{c}\text { Fujii et al. [29] } \\
\begin{array}{c}\text { Case report } \\
\text { Huang et al. [31] } \\
\text { Prospective }\end{array}\end{array}$ & 1 & 100 & 100 & FNA/22G & 1 & None \\
\hline
\end{tabular}

\subsection{EUS-Guided Varices Diagnosis}

In cirrhotic patients, elevated liver stiffness as measured by TE could predict the presence of large esophageal varices [32]. The use of EUS in the diagnosis and management of gastric varices has expanded in the last decade. Gastric varices (GVs) are generally classified by the Sarin's classification system [33], taking into account the location and direction of blood flow. The gastroesophageal varices $1(\mathrm{GOV}-1)$ is the most prevalent type and represents the extension of esophageal varices alongside the gastric lesser curvature. The GOV-2 type is the extension of esophageal varices along the greater curvature. The third and less common type is the isolated GV (IGV), consisting in isolated gastric varices localized in the upper gastric region, particularly the fundus. These GVs arise due to splenorenal or gastrorenal shunts. The GOV-1 type is generally associated with a lower risk of bleeding compared to GOV-2 and IGV, which represent the major source [34]. Several studies have established the advantage of EUS over upper gastrointestinal endoscopy in the recognition of all types of gastric varices [35]. Imamura et al. showed that the diameter of gastric varices was associated with flow volume, irrespective of the Child-Pugh class [36]. The addition of duplex and color Doppler EUS were assessed in a study including 20 volunteers and 11 patients with suspected splenic and/or portal thrombosis with possible shunts. The duplex and Doppler EUS provided a correct diagnosis in 10 out of 11 patients, whereas transabdominal US was unsuccessful to reach an accurate diagnosis in all patients. This finding shed light on the evolving role of EUS on the detection of splenic and portal veins thrombosis or a portosystemic shunt [37].

\section{EUS-Guided Liver Biopsy}

\subsection{EUS-Guided Biopsy in Chronic Liver Diseases}

Despite the great advance in the production of noninvasive tests intended to quantify liver fibrosis in patients with chronic liver diseases, their accuracy is inconclusive in a large proportion of cases, and thus liver biopsy is still the gold standard [9]. With our expanding experience and the continued progress in EUS-dedicated needles, tissue acquisition has improved to add another tool to our armamentarium [38]. Since its first description in 2007 [39], and compared with other modalities of liver biopsy, it was shown that EUS-guided liver biopsy (EUS-LB) using 19-gauge fine needle 
aspiration (FNA) needles is safe, with a yield comparable to or higher than percutaneous or transjugular biopsy [40]. To date, several studies have evaluated the diagnostic yield, accuracy, and safety profile of EUS-LB in patients with chronic liver diseases of various causes. In 2012, Stavropoulos et al. provided "proof of concept" that tissue acquisition with the regular 19-gauge EUS-FNA needle is adequate and that EUS-LB could be successfully performed with this needle [41]. Several years later, a prospective study comparing 19-gauge FNA versus 19-gauge fine needle biopsy (FNB) needles demonstrated a better performance of the core biopsy needle concerning the biopsy length and number of complete portal triads [42]. On the other hand, a prospective study comparing 19-gauge FNA with 22-gauge FNB showed higher tissue adequacy of the 19-gauge FNA in terms of sample length and less sample fragmentation [43]. However, in a recent meta-analysis of studies using 19-gauge needles, tissue acquisition was better in the FNA needles compared with the core biopsy needles, with a diagnostic yield of $95.8 \%$ and adverse events rate of $0.9 \%$ [44]. The superiority of the 19-gauge FNA needle in terms of specimen adequacy compared with the 22-gauge FNB needle and two types of 19-gauge FNB needle (one true cut and the other non-true cut) was also shown in a very recent study by Patel et al. [45]. A meta-analysis by Khan et al. summarized that cytological assessment of material obtained by FNA is proven to be sufficient; however, in cases needing tissue architecture examination, immunohistochemical staining, and molecular analysis, FNB is preferred to allow tissue acquisition for histologic examination [46]. The most prominent advantages of EUS-LB are that it relies on minor pain intensity as it does not include skin puncture, with image guidance thus ensuring blood vessel avoidance, providing access to all liver parenchyma including the entire left lobe and the majority of the right lobe. This allows quick and safe multiple liver passes from both lobes, thus decreasing histologic variability and providing same-session inspection of neighboring structures and lymph nodes and screening for varices [47]. As most US-guided, CT-guided, and transjugular liver biopsies are obtained from the right lobe, and as several studies reported variations in disease activity and staging in different liver lobes, a study by Khurana et al. showed that EUS-guided bi-lobar liver biopsy improved disease activity and fibrosis assessments. They concluded that EUS guidance enables sampling of both liver lobes at the same session and can be readily applied in clinical practice [48]. A recent review by Mok et al. has shown that EUS-LB is a safe and effective modality for liver core acquisition [49]. A systematic review by Wang et al. reported an EUS-FNA-related morbidity and mortality of $0.98 \%$ and $0.02 \%$, respectively [50]. Tables 2 and 3 show all studies addressing the utility of EUS-guided liver biopsy in parenchymal liver diseases. Overall, we could identify 16 papers including 913 patients. Among them, seven were retrospective studies and cases series, two were case reports, and the others were prospective non-randomized, prospective case series, and randomized controlled trials. The average technical success and diagnostic yield for EUS-FNA and EUS-FNB-guided liver biopsy were $100 \%$ and $89.8 \%$, respectively, while complications occurred in 30 patients, yielding a complications rate of $3.3 \%$, all of which were minor. Further comparison between the EUS-FNA and EUS-FNB groups revealed no difference in terms of technical success (100\% for both), diagnostic yield of $97.4 \%$ for EUS-FNA vs. $87.6 \%$ for EUS-FNB $(p=0.09)$, average median specimen length of $31.5 \mathrm{~mm}$ for EUS-FNA vs. 30.8 for EUS-FNB $(p=0.4)$, average median complete portal tracts of 11.2 for EUS-FNA vs. 17.1 for EUS-FNB $(p=0.2)$, and similar average median needle passes of 2.2 for EUS-FNA vs. 2 for EUS-FNB $(p=0.3)$. However, there was a trend towards more procedure-related complications in the EUS-FNB studies compared to EUS-FNA studies (29/592 patients, 4.9\%, vs. 1/321 patients, $0.3 \%, p=0.07)$. Notably, data regarding the safety profile of EUS-LB in cirrhotic patients are lacking, thus more prospective studies with large sample sizes are needed. Moreover, there are no available studies that have assessed the cut-off levels of the coagulation profile and platelets counts permitting the safe performance of EUS-LB. Hence, more studies are needed to address these issues also before setting guideline recommendations. 


\subsection{EUS and Non-Alcoholic Fatty Liver Disease}

In Western countries, non-alcoholic fatty liver disease (NAFLD), with its evolutive form called nonalcoholic steatohepatitis (NASH), represents one of the major causes of chronic liver disease [51]. NAFLD is usually suspected by the combination of abnormal liver transaminases, hyperechoic liver on US, and the absence of heavy alcohol drinking and any other chronic liver disease cause [48]. The staging of fibrosis by the noninvasive fibroscan is suboptimal, especially in stages F2 and F3 [52]. Hence, LB remains a gold standard in diagnosing the advanced forms (F3) [53]. As the number of $\mathrm{NASH}$ patients and the expanding potential pharmacologic therapies for this condition are increasing, it seems that the need for LB for disease staging will also increase [54]. Because EUS-LB enjoys US guidance, this may improve its yield by directing the needle to the fattiest area [55]. To date, only two studies have reported the utility of EUS-LB in a cohort of patients with NAFLD (Table 4). The largest cohort was evaluated by Saab et al. and includes 47 patients with fatty liver who underwent EUS-FNB with 19-gauge SharkCore needle biopsy with high diagnostic yield and technical success, while only two patients developed a minor self-limited liver hematoma that resolved with conservative management [56]. Another study, performed by Bazerbachi et al., reported a similar efficacy and safety rate among 21 patients with NAFLD using a 22G SharkCore FNB needle, with minimal adverse events occurring in six patients, which were all limited to mild post-procedural pain [55]. We analyzed all studies that were performed in patients with chronic liver diseases (Tables 2 and 3 ), extracting the data regarding the NAFLD subgroup patients alone from the entire study cohort and analyzed their data independently. We identified five studies, as shown in Table 4. All studies reported an excellent technical success, diagnostic yield, and zero complications rate [57], suggesting the high efficacy and safety of both needle types, FNA and FNB, in obtaining LB via EUS. Notably, all other studies reported in Table 2 and those that assessed the EUS-LB in chronic liver diseases were not included into our analysis shown in Table 4 given that they lack independent analysis of the NAFLD patients' subgroup. Overall, we could identify seven papers (overall, 103 patients), all of which were case series studies, where four of them had a retrospective design while the rest had a prospective design. The average technical success and diagnostic yield were $100 \%$ and $96.8 \%$, respectively, while complications occurred in 8 patients, yielding a complications rate of $7.7 \%$, all of which were mild. 
Table 2. Studies reporting the efficacy and safety of EUS-FNA-guided liver biopsy in patients with chronic liver disease.

\begin{tabular}{|c|c|c|c|c|c|c|c|c|}
\hline Reference & Patients No. & $\begin{array}{c}\text { Technical } \\
\text { Success (\%) }\end{array}$ & $\begin{array}{l}\text { Diagnostic } \\
\text { Yield (\%) }\end{array}$ & $\begin{array}{l}\text { Specimen Length in } \\
\text { mm (Median, Range) }\end{array}$ & $\begin{array}{l}\text { Complete Portal Tracts } \\
\text { (Median, Range) }\end{array}$ & $\begin{array}{c}\text { Complications, } \\
\text { N (\%) }\end{array}$ & $\begin{array}{l}\text { Needle Passes } \\
\text { (Median) }\end{array}$ & $\begin{array}{c}\text { Needle } \\
\text { Used/Size }\end{array}$ \\
\hline $\begin{array}{l}\text { Pineda et al. [40] } \\
\text { Retrospective study }\end{array}$ & 110 & 100 & 98 & $38(24-81)$ & $14(9-27)$ & 0 & - & FNA/19G \\
\hline $\begin{array}{l}\text { Shuja et al. [47] } \\
\text { Retrospective study }\end{array}$ & 69 & 100 & 100 & 45.8 (mean) & 10.84 (mean) & 0 & 3 & FNA/19G \\
\hline $\begin{array}{l}\text { Stavropoulos et al. [41] } \\
\text { Prospective case series }\end{array}$ & 22 & 100 & 91 & $36.9(2-184.6)$ & $9(1-73)$ & 0 & $2(1-3)$ & FNA/19G \\
\hline $\begin{array}{c}\text { Diehl et al. [58] } \\
\text { Prospective non-randomized study }\end{array}$ & 110 & 100 & 98 & $38(0-203)$ & $14(0-68)$ & $1(0.9)^{a}$ & $1.5(1-2)$ & FNA/19 \\
\hline $\begin{array}{c}\text { Gor et al. [59] } \\
\text { Retrospective case series }\end{array}$ & 10 & 100 & 100 & $13(6-23)$ & $8(6-15)$ & 0 & - & FNA/19G \\
\hline
\end{tabular}

Table 3. Studies reporting the efficacy and safety of EUS-FNB-guided liver biopsy in patients with chronic liver disease.

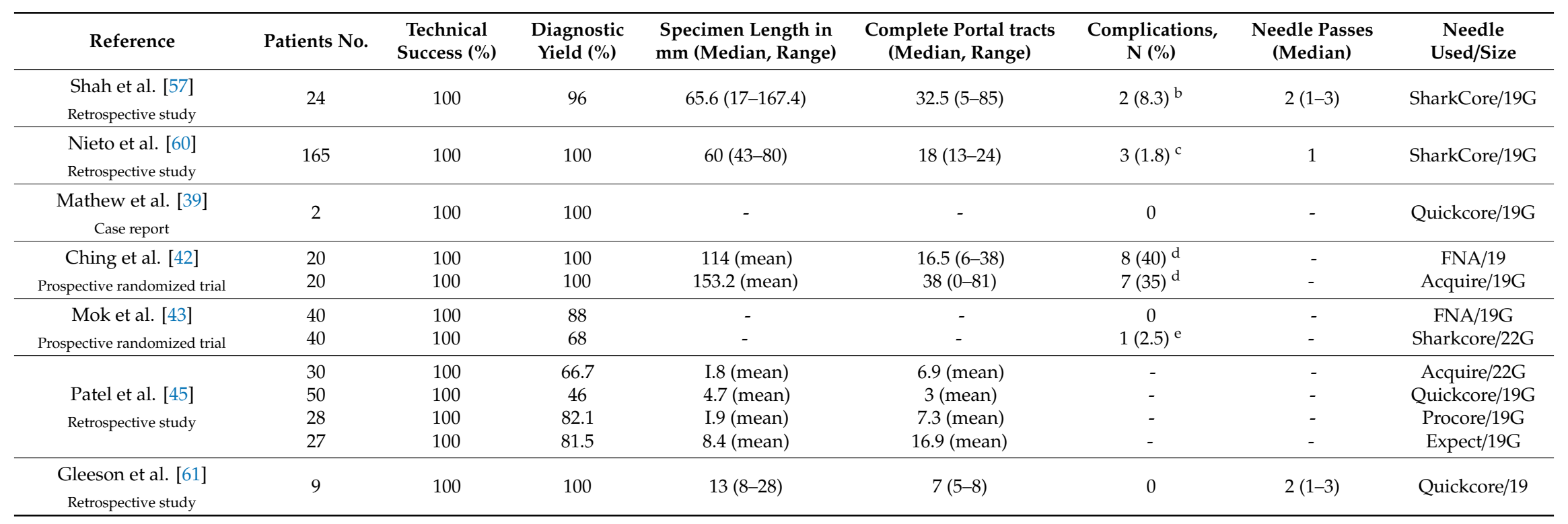


Table 3. Cont.

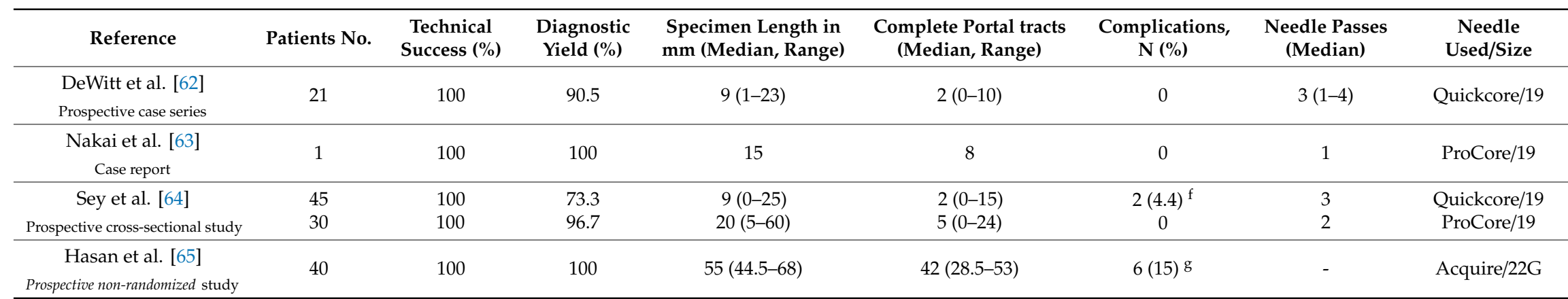

${ }^{\mathrm{b}}$ Mild abdominal pain (1) and subcapsular bleeding (1); ${ }^{\mathrm{c}}$ Abdominal pain (2) and self-limited hematoma (1); ${ }^{\mathrm{d}}$ Mild abdominal pain (15); ${ }^{\mathrm{e}}$ abdominal pain (1); ${ }^{\mathrm{f}}$ Mild abdominal pain (2);

g Self-limited abdominal pain (6).

Table 4. Studies reporting the efficacy and safety of EUS-guided liver biopsy in non-alcoholic fatty liver disease.

\begin{tabular}{|c|c|c|c|c|c|c|c|c|}
\hline Reference & Patients No. & $\begin{array}{c}\text { Technical } \\
\text { Success (\%) }\end{array}$ & $\begin{array}{l}\text { Diagnostic } \\
\text { Yield (\%) }\end{array}$ & $\begin{array}{l}\text { Specimen Length in } \\
\text { mm (Median, Range) }\end{array}$ & $\begin{array}{l}\text { Complete Portal Tracts } \\
\text { (Median, Range) }\end{array}$ & $\begin{array}{c}\text { Complications, } \\
\text { N (\%) }\end{array}$ & $\begin{array}{c}\text { Needle Passes } \\
\text { (Median) }\end{array}$ & $\begin{array}{c}\text { Needle } \\
\text { Used/Size }\end{array}$ \\
\hline $\begin{array}{c}\text { Saab et al. [56] } \\
\text { Retrospective case series }\end{array}$ & 47 & 100 & 100 & $65(46-80)$ & $18(14-24)$ & $2(4.2)^{\mathrm{a}}$ & 1 & SharkCore/19G \\
\hline $\begin{array}{l}\text { Bazerbachi et al. [55] } \\
\text { Prospective blinded trial }\end{array}$ & 21 & 100 & 100 & $24(20-27.5)$ & $26(7-62)$ & $6(7)^{b}$ & 2 & SharkCore/22 \\
\hline $\begin{array}{l}\text { Dewitt et al. [62] } \\
\text { Prospective case series }\end{array}$ & 9 & 100 & 77.8 & $8(1-13)$ & $2(0-9)$ & 0 & 3 & Quickcore/19G \\
\hline $\begin{array}{c}\text { Gleeson et al. [61] } \\
\text { Retrospective case series }\end{array}$ & 6 & 100 & 100 & $11.5(8-27)$ & $7(5-8)$ & 0 & $2(1-3)$ & Quickcore/19G \\
\hline $\begin{array}{c}\text { Gor et al. [59] } \\
\text { Retrospective case series }\end{array}$ & 4 & 100 & 100 & $11(6-23)$ & $6.5(6-14)$ & 0 & - & FNA/19G \\
\hline $\begin{array}{l}\text { Stavropoulos et al. [41] } \\
\text { Prospective case series }\end{array}$ & 5 & 100 & 100 & $32.2(12.5-58.7)$ & $9(4-13)$ & 0 & 1 & FNA/19G \\
\hline $\begin{array}{c}\text { Shah et al. [57] } \\
\text { Retrospective }\end{array}$ & 11 & 100 & 100 & $71.1(17.1-167.4)$ & $33(23-85)$ & - & $2(1-3)$ & SharkCore/19G \\
\hline
\end{tabular}

${ }^{a}$ Self-limited liver hematoma that resolved with conservative management (2 patients); ${ }^{\mathrm{b}}$ Postprocedural pain (6). 


\subsection{EUS and Focal Liver Lesions}

As tissue diagnosis is usually needed in most liver lesions and especially in otherwise indeterminate hepatic solid masses, needle biopsy is the next step. Not infrequently, immunohistochemical staining may be needed to allow differentiation between different hepatic solid masses where cytological evaluation alone may not be sufficient. To date, several studies have reported the diagnostic yield of EUS-FNA/FNB in liver masses. The largest study was performed by TenBerge et al. on 167 cases in which EUS-FNA of the liver was performed, and showed an excellent overall diagnostic yield of 95.8\% for malignant and benign liver lesions, as the findings of the cytopathology was malignancy in $138(82.6 \%)$, benign in $22(13.2 \%)$, and indeterminate in $7(4 \%)$, with a $3.6 \%$ complication rate [66]. Moreover, a retrospective analysis evaluating the accuracy of EUS-FNB in hepatic solid masses showed a high diagnostic accuracy $(89.7 \%)$, sensitivity $(89.7 \%)$, specificity $(100 \%)$, and sample adequacy $(91.4 \%)$ for histology [67]. A recent review by Ichim et al. reached the conclusion that EUS-FNA of focal hepatic lesions is comparable, if not superior, to US/CT-guided biopsy, with a diagnostic yield of $80-100 \%$ [68]. Although this data is still emerging, according to the available literature, both needle types (FNA and FNB) have a similar efficacy and safety profile. Overall, we could identify nine papers, including six prospective and three retrospective studies (overall 463 patients) (Table 5). The average diagnostic yield was excellent, approaching $94.8 \%$, while only 7 patients had complications, yielding a complications rate of $1.5 \%$. Still, more prospective comparative studies are needed to more precisely assess the performance of FNA and FNB needles.

Table 5. Studies reporting the utility of EUS-guided liver biopsy in focal liver lesions.

\begin{tabular}{|c|c|c|c|c|c|}
\hline Reference & Patients No. & $\begin{array}{l}\text { Diagnostic } \\
\text { Yield (\%) }\end{array}$ & $\begin{array}{c}\text { Complications, } \\
\text { N (\%) }\end{array}$ & $\begin{array}{l}\text { Needle Passes, } \\
\text { Median }\end{array}$ & Needle Used/Size \\
\hline $\begin{array}{l}\text { Ichim et al. [4] } \\
\text { Prospective study }\end{array}$ & 48 & 98 & 0 & 2 & FNA/22G \\
\hline $\begin{array}{l}\text { Sing et al. [18] } \\
\text { Prospective study }\end{array}$ & 26 & 98 & 0 & 2.1 & FNA/22 \\
\hline $\begin{array}{c}\text { TenBerge et al. [66] } \\
\text { Retrospective study }\end{array}$ & 167 & 95.8 & $6(3.6)^{a}$ & - & FNA/- \\
\hline $\begin{array}{l}\text { Chon et al. [67] } \\
\text { Retrospective study }\end{array}$ & 58 & 89.7 & $1(1.7)^{b}$ & 2 & $\begin{array}{c}\text { FNB ProCore/20 or } \\
22 \text { or } 25 \mathrm{G}\end{array}$ \\
\hline $\begin{array}{l}\text { Nguyen et al. [69] } \\
\text { Prospective study }\end{array}$ & 14 & 100 & 0 & 2 & FNA/22G \\
\hline $\begin{array}{l}\text { DeWitt et al. [70] } \\
\text { Retrospective study }\end{array}$ & 77 & 91 & 0 & 3.4 (mean) & FNA/22 \\
\hline $\begin{array}{c}\text { McGrath et al. [71] } \\
\text { Retrospective study }\end{array}$ & 5 & 100 & 0 & 2 & FNA/22 \\
\hline $\begin{array}{l}\text { Lee et al. [72] } \\
\text { Prospective study }\end{array}$ & 21 & 90.5 & 0 & 2 & $\begin{array}{c}\mathrm{FNB} / 20 \mathrm{G} \text { or } 22 \mathrm{G} \text { or } \\
25 \mathrm{G}\end{array}$ \\
\hline $\begin{array}{l}\text { Oh D. et al. [73] } \\
\text { Prospective observational study }\end{array}$ & 47 & 90.5 & 0 & 3 & FNA/22 or 25 \\
\hline
\end{tabular}

\section{Conclusions}

This interesting rapidly evolving field of EUS in liver diseases diagnosis has induced a big step in several aspects, including improved visualization of liver lesions and better tissue acquisition of diffuse and focal hepatic lesions, in addition to measuring portal pressure and diagnosing gastric varices, due to its high spatial resolution, proximity of the transducer to the organ of interest, and minimal invasiveness and excellent safety profile. This state-of-the-art review demonstrates the promising evolving diagnostic potential of this technique, as it was shown to be consistently effective with a high safety profile across the various studies reported. Probably, in the next years, some of our first-line 
recommended approaches will change in favor of these rapidly growing and expanding applications to cover almost all aspects of diagnostic hepatology.

Author Contributions: T.K. and W.S. contributed to study design and conception. W.S., A.K., M.M., R.P., A.M., and T.K. contributed to data collection, analysis and interpretation. T.K. and W.S. wrote the draft of the manuscript. All authors have read and agreed to the published version of the manuscript.

Funding: This research received no external funding.

Conflicts of Interest: The authors declare no conflict of interest regarding this manuscript.

\section{Abbreviations}

$\begin{array}{ll}\text { EUS } & \text { endoscopic ultrasound } \\ \text { US } & \text { ultrasound } \\ \text { CT } & \text { computed tomography } \\ \text { RTE } & \text { real-time elastography } \\ \text { CE } & \text { Contrast-Enhancement } \\ \text { EASL } & \text { European association for the study of liver disease } \\ \text { TE } & \text { transient elastography } \\ \text { LFI } & \text { Liver fibrosis index } \\ \text { MRI } & \text { magnetic resonance imaging } \\ \text { UCA } & \text { ultrasound contrast agents } \\ \text { CE-EUS } & \text { contrast-enhanced-EUS } \\ \text { CH-EUS } & \text { contrast harmonic-EUS } \\ \text { PPG } & \text { portal pressure gradient } \\ \text { PV } & \text { portal vein } \\ \text { HV } & \text { hepatic vein } \\ \text { IVC } & \text { inferior vena cava } \\ \text { GV } & \text { Gastric varices } \\ \text { GOV } & \text { gastroesophageal varices } \\ \text { IGV } & \text { isolated gastric varices } \\ \text { EUS-LB } & \text { endoscopic ultrasound-guided liver biopsy } \\ \text { FNA } & \text { fine needle aspiration } \\ \text { FNB } & \text { fine needle biopsy } \\ \text { NAFLD } & \text { non-alcoholic fatty liver disease } \\ \text { NASH } & \text { nonalcoholic steatohepatitis } \\ & \end{array}$

\section{References}

1. Friedberg, S.R.; Lachter, J. Endoscopic ultrasound: Current roles and future directions. World J. Gastrointest. Endosc. 2017, 9, 499-505. [CrossRef] [PubMed]

2. Candoli, P.; Ceron, L.; Trisolini, R.; Romagnoli, M.; Michieletto, L.; Scarlata, S.; Galasso, T.; Leoncini, F.; Pasini, V.; Dennetta, D.; et al. Competence in endosonographic techniques. Panminerva Med. 2019, 61, 249-279. [CrossRef] [PubMed]

3. Andanappa, H.K.; Dai, Q.; Korimilli, A.; Panganamamula, K.; Friedenberg, F.; Miller, L. Acoustic liver biopsy using endoscopic ultrasound. Dig. Dis. Sci. 2008, 53, 1078-1083. [CrossRef] [PubMed]

4. Ichim, V.A.; Chira, R.I.; Mircea, P.A.; Nagy, G.A.; Crisan, D.; Socaciu, M.A. Accuracy of endoscopic ultrasound-guided biopsy of focal liver lesions. Med. Ultrason. 2020, 22, 20-25. [CrossRef] [PubMed]

5. Campos, S.; Poley, J.W.; van Driel, L.; Bruno, M.J. The role of EUS in diagnosis and treatment of liver disorders. Endosc. Int. Open 2019, 7, E1262-E1275. [CrossRef] [PubMed]

6. Wiechowska-Kozlowska, A.; Zasada, K.; Milkiewicz, M.; Milkiewicz, P. Correlation between Endosonographic and Doppler Ultrasound Features of Portal Hypertension in Patients with Cirrhosis. Gastroenterol. Res. Pract. 2012, 2012, 395345. [CrossRef]

7. Claudon, M.; Dietrich, C.F.; Choi, B.I.; Cosgrove, D.O.; Kudo, M.; Nolsoe, C.P.; Piscaglia, F.; Wilson, S.R.; Barr, R.G.; Chammas, M.C.; et al. Guidelines and good clinical practice recommendations for Contrast Enhanced Ultrasound (CEUS) in the liver-update 2012: A WFUMB-EFSUMB initiative in cooperation with representatives of AFSUMB, AIUM, ASUM, FLAUS and ICUS. Ultrasound Med. Biol. 2013, 39, 187-210. [CrossRef] 
8. Choudhary, N.; Bansal, R.K.; Puri, R.; Singh, R.R.; Nasa, M.; Shah, V.; Sarin, H.; Guleria, M.; Saigal, S.; Saraf, N.; et al. Impact and safety of endoscopic ultrasound guided fine needle aspiration on patients with cirrhosis and pyrexia of unknown origin in India. Endosc. Int. Open 2016, 4, E953-E956. [CrossRef]

9. European Association for Study of Liver; Asociacion Latinoamericana para el Estudio del Higado. EASL-ALEH Clinical Practice Guidelines: Non-invasive tests for evaluation of liver disease severity and prognosis. J. Hepatol. 2015, 63, 237-264. [CrossRef]

10. Berzigotti, A.; Ashkenazi, E.; Reverter, E.; Abraldes, J.G.; Bosch, J. Non-invasive diagnostic and prognostic evaluation of liver cirrhosis and portal hypertension. Dis. Markers 2011, 31, 129-138. [CrossRef]

11. Tatsumi, C.; Kudo, M.; Ueshima, K.; Kitai, S.; Ishikawa, E.; Yada, N.; Hagiwara, S.; Inoue, T.; Minami, Y.; Chung, H.; et al. Non-invasive evaluation of hepatic fibrosis for type C chronic hepatitis. Intervirology 2010, 53, 76-81. [CrossRef] [PubMed]

12. Rimbas, M.; Gheonea, D.I.; Sandulescu, L.; Saftoiu, A.; Vilmann, P.; Ciurea, T. EUS Elastography in Evaluating Chronic Liver Disease. Why not from Inside? Curr. Health Sci. J. 2009, 35, 225-227. [PubMed]

13. Schulman, A.R.; Lin, M.V.; Rutherford, A.; Chan, W.W.; Ryou, M. A Prospective Blinded Study of Endoscopic Ultrasound Elastography in Liver Disease: Towards a Virtual Biopsy. Clin. Endosc. 2018, 51, 181-185. [CrossRef] [PubMed]

14. Marques, S.; Carmo, J.; Tulio, M.A.; Bispo, M.; Matos, L.; Chagas, C. Diagnostic Performance of Real-Time Elastography in the Assessment of Advanced Fibrosis in Chronic Hepatitis C. GE Port. J. Gastroenterol. 2016, 23, 13-18. [CrossRef]

15. Tu, C.H.; Li, J.; Wang, C.Y.; Zhou, L.; Ma, Y.; Gao, M.; Wang, J.; Zeng, Q.M.; Lu, W. [Diagnostic value of endoscopic ultrasonography, fibroscan, acoustic radiation pulse imaging, serological index, and their combination for early stage liver cirrhosis]. Zhonghua Gan Zang Bing Za Zhi 2019, 27, 615-620. [CrossRef]

16. Singh, P.; Erickson, R.A.; Mukhopadhyay, P.; Gopal, S.; Kiss, A.; Khan, A.; Ulf Westblom, T. EUS for detection of the hepatocellular carcinoma: Results of a prospective study. Gastrointest. Endosc. 2007, 66, 265-273. [CrossRef]

17. Awad, S.S.; Fagan, S.; Abudayyeh, S.; Karim, N.; Berger, D.H.; Ayub, K. Preoperative evaluation of hepatic lesions for the staging of hepatocellular and metastatic liver carcinoma using endoscopic ultrasonography. Am. J. Surg. 2002, 184, 601-604. [CrossRef]

18. Singh, P.; Mukhopadhyay, P.; Bhatt, B.; Patel, T.; Kiss, A.; Gupta, R.; Bhat, S.; Erickson, R.A. Endoscopic ultrasound versus CT scan for detection of the metastases to the liver: Results of a prospective comparative study. J. Clin. Gastroenterol. 2009, 43, 367-373. [CrossRef]

19. Sandrin, L.; Fourquet, B.; Hasquenoph, J.M.; Yon, S.; Fournier, C.; Mal, F.; Christidis, C.; Ziol, M.; Poulet, B.; Kazemi, F.; et al. Transient elastography: A new noninvasive method for assessment of hepatic fibrosis. Ultrasound Med. Biol. 2003, 29, 1705-1713. [CrossRef]

20. Rustemovic, N.; Hrstic, I.; Opacic, M.; Ostojic, R.; Jakic-Razumovic, J.; Kvarantan, M.; Pulanic, R.; Vucelic, B. EUS elastography in the diagnosis of focal liver lesions. Gastrointest. Endosc. 2007, 66, 823-824. [CrossRef]

21. Sandulescu, L.; Padureanu, V.; Dumitrescu, C.; Braia, N.; Streba, C.T.; Gheonea, D.I.; Cazacu, S.; Ciurea, T.; Rogoveanu, I.; Saftoiu, A. A pilot study of real time elastography in the differentiation of focal liver lesions. Curr. Health Sci. J. 2012, 38, 32-35. [PubMed]

22. Kitano, M.; Kamata, K. Contrast-enhanced harmonic endoscopic ultrasound: Future perspectives. Endosc. Ultrasound 2016, 5, 351-354. [CrossRef] [PubMed]

23. Fusaroli, P.; Napoleon, B.; Gincul, R.; Lefort, C.; Palazzo, L.; Palazzo, M.; Kitano, M.; Minaga, K.; Caletti, G.; Lisotti, A. The clinical impact of ultrasound contrast agents in EUS: A systematic review according to the levels of evidence. Gastrointest. Endosc. 2016, 84, 587-596. [CrossRef] [PubMed]

24. Cosgrove, D.; Blomley, M. Liver tumors: Evaluation with contrast-enhanced ultrasound. Abdom. Imaging 2004, 29, 446-454. [CrossRef] [PubMed]

25. Oh, D.; Seo, D.W.; Hong, S.M.; Jun, J.H.; Song, T.J.; Park, D.H.; Son, B.K.; Lee, S.S.; Lee, S.K.; Kim, M.H. The usefulness of contrast-enhanced harmonic EUS-guided fine-needle aspiration for evaluation of hepatic lesions (with video). Gastrointest. Endosc. 2018, 88, 495-501. [CrossRef] [PubMed]

26. Augustin, S.; Millan, L.; Gonzalez, A.; Martell, M.; Gelabert, A.; Segarra, A.; Serres, X.; Esteban, R.; Genesca, J. Detection of early portal hypertension with routine data and liver stiffness in patients with asymptomatic liver disease: A prospective study. J. Hepatol. 2014, 60, 561-569. [CrossRef] 
27. Carrion, J.A.; Navasa, M.; Bosch, J.; Bruguera, M.; Gilabert, R.; Forns, X. Transient elastography for diagnosis of advanced fibrosis and portal hypertension in patients with hepatitis $\mathrm{C}$ recurrence after liver transplantation. Liver Transpl. 2006, 12, 1791-1798. [CrossRef]

28. Samarasena, J.B.; Chang, K.J. Endoscopic Ultrasound-Guided Interventions for the Measurement and Treatment of Portal Hypertension. Gastrointest. Endosc. Clin. N. Am. 2019, 29, 311-320. [CrossRef]

29. Fujii-Lau, L.L.; Leise, M.D.; Kamath, P.S.; Gleeson, F.C.; Levy, M.J. Endoscopic ultrasound-guided portal-systemic pressure gradient measurement. Endoscopy 2014, 46 (Suppl. 1 UCTN), E654-E656. [CrossRef]

30. Huang, J.Y.; Samarasena, J.B.; Tsujino, T.; Chang, K.J. EUS-guided portal pressure gradient measurement with a novel 25-gauge needle device versus standard transjugular approach: A comparison animal study. Gastrointest. Endosc. 2016, 84, 358-362. [CrossRef]

31. Huang, J.Y.; Samarasena, J.B.; Tsujino, T.; Lee, J.; Hu, K.Q.; McLaren, C.E.; Chen, W.P.; Chang, K.J. EUS-guided portal pressure gradient measurement with a simple novel device: A human pilot study. Gastrointest. Endosc. 2017, 85, 996-1001. [CrossRef] [PubMed]

32. Kazemi, F.; Kettaneh, A.; N’Kontchou, G.; Pinto, E.; Ganne-Carrie, N.; Trinchet, J.C.; Beaugrand, M. Liver stiffness measurement selects patients with cirrhosis at risk of bearing large oesophageal varices. J. Hepatol. 2006, 45, 230-235. [CrossRef] [PubMed]

33. Sarin, S.K.; Kumar, A. Gastric varices: Profile, classification, and management. Am. J. Gastroenterol. 1989, 84, 1244-1249. [PubMed]

34. Hashizume, M.; Kitano, S.; Yamaga, H.; Koyanagi, N.; Sugimachi, K. Endoscopic classification of gastric varices. Gastrointest. Endosc. 1990, 36, 276-280. [CrossRef]

35. Caletti, G.; Brocchi, E.; Baraldini, M.; Ferrari, A.; Gibilaro, M.; Barbara, L. Assessment of portal hypertension by endoscopic ultrasonography. Gastrointest. Endosc. 1990, 36, S21-S27. [CrossRef]

36. Imamura, H.; Irisawa, A.; Shibukawa, G.; Takagi, T.; Hikichi, T.; Obara, K.; Ohira, H. Echo-endoscopic analysis of variceal hemodynamics in patient with isolated gastric varices. Endosc. Ultrasound 2014, 3, 238-244. [CrossRef]

37. Pontes, J.M.; Leitao, M.C.; Portela, F.A.; Rosa, A.M.; Ministro, P.; Freitas, D.S. Endoscopic ultrasonography in the treatment of oesophageal varices by endoscopic sclerotherapy and band ligation: Do we need it? Eur. J. Gastroenterol. Hepatol. 1995, 7, 41-46.

38. DiMaio, C.J.; Kolb, J.M.; Benias, P.C.; Shah, H.; Shah, S.; Haluszka, O.; Maranki, J.; Sharzehi, K.; Lam, E.; Gordon, S.R.; et al. Initial experience with a novel EUS-guided core biopsy needle (SharkCore): Results of a large North American multicenter study. Endosc. Int. Open 2016, 4, E974-E979. [CrossRef]

39. Mathew, A. EUS-guided routine liver biopsy in selected patients. Am. J. Gastroenterol. 2007, 102, $2354-2355$. [CrossRef]

40. Pineda, J.J.; Diehl, D.L.; Miao, C.L.; Johal, A.S.; Khara, H.S.; Bhanushali, A.; Chen, E.Z. EUS-guided liver biopsy provides diagnostic samples comparable with those via the percutaneous or transjugular route. Gastrointest. Endosc. 2016, 83, 360-365. [CrossRef]

41. Stavropoulos, S.N.; Im, G.Y.; Jlayer, Z.; Harris, M.D.; Pitea, T.C.; Turi, G.K.; Malet, P.F.; Friedel, D.M.; Grendell, J.H. High yield of same-session EUS-guided liver biopsy by 19-gauge FNA needle in patients undergoing EUS to exclude biliary obstruction. Gastrointest. Endosc. 2012, 75, 310-318. [CrossRef] [PubMed]

42. Ching-Companioni, R.A.; Diehl, D.L.; Johal, A.S.; Confer, B.D.; Khara, H.S. 19 G aspiration needle versus $19 \mathrm{G}$ core biopsy needle for endoscopic ultrasound-guided liver biopsy: A prospective randomized trial. Endoscopy 2019, 51, 1059-1065. [CrossRef] [PubMed]

43. Mok, S.R.S.; Diehl, D.L.; Johal, A.S.; Khara, H.S.; Confer, B.D.; Mudireddy, P.R.; Kovach, A.H.; Diehl, M.M.; Kirchner, H.L.; Chen, Z.E. Endoscopic ultrasound-guided biopsy in chronic liver disease: A randomized comparison of 19-G FNA and 22-G FNB needles. Endosc. Int. Open 2019, 7, E62-E71. [CrossRef]

44. Mohan, B.P.; Shakhatreh, M.; Garg, R.; Ponnada, S.; Adler, D.G. Efficacy and safety of EUS-guided liver biopsy: A systematic review and meta-analysis. Gastrointest. Endosc. 2019, 89, 238-246. [CrossRef] [PubMed]

45. Patel, H.K.; Saxena, R.; Rush, N.; Patel, S.K.; Dasari, C.S.; Mneimneh, W.; Quickery, A.; Rahal, M.A.; Temnykh, L.; DeWitt, J.; et al. A Comparative Study of 22G versus 19G Needles for EUS-Guided Biopsies for Parenchymal Liver Disease: Are Thinner Needles Better? Dig. Dis. Sci. 2020. [CrossRef] [PubMed] 
46. Khan, M.A.; Grimm, I.S.; Ali, B.; Nollan, R.; Tombazzi, C.; Ismail, M.K.; Baron, T.H. A meta-analysis of endoscopic ultrasound-fine-needle aspiration compared to endoscopic ultrasound-fine-needle biopsy: Diagnostic yield and the value of onsite cytopathological assessment. Endosc. Int. Open. 2017, 5, E363-E375. [CrossRef] [PubMed]

47. Shuja, A.; Alkhasawneh, A.; Fialho, A.; Fialho, A.; Shukri, A.; Harris, C.; Smotherman, C.; Malespin, M.; de Melo, S.W., Jr. Comparison of EUS-guided versus percutaneous and transjugular approaches for the performance of liver biopsies. Dig. Liver Dis. 2019, 51, 826-830. [CrossRef]

48. Khurana, S.; Butt, W.; Khara, H.S.; Johal, A.S.; West, S.F.; Chen, Z.E.; Berger, A.L.; Diehl, D.L. Bi-lobar liver biopsy via EUS enhances the assessment of disease severity in patients with non-alcoholic steatohepatitis. Hepatol. Int. 2019, 13, 323-329. [CrossRef]

49. Mok, S.R.S.; Diehl, D.L. The Role of EUS in Liver Biopsy. Curr. Gastroenterol. Rep. 2019, 21, 6. [CrossRef]

50. Wang, K.X.; Ben, Q.W.; Jin, Z.D.; Du, Y.Q.; Zou, D.W.; Liao, Z.; Li, Z.S. Assessment of morbidity and mortality associated with EUS-guided FNA: A systematic review. Gastrointest. Endosc. 2011, 73, 283-290. [CrossRef]

51. Saracco, G.M.; Evangelista, A.; Fagoonee, S.; Ciccone, G.; Bugianesi, E.; Caviglia, G.P.; Abate, M.L.; Rizzetto, M.; Pellicano, R.; Smedile, A. Etiology of chronic liver diseases in the Northwest of Italy, 1998 through 2014. World J. Gastroenterol. 2016, 22, 8187-8193. [CrossRef] [PubMed]

52. Boursier, J.; Cales, P. Clinical interpretation of Fibroscan(R) results: A real challenge. Liver Int. 2010, 30, 1400-1402. [CrossRef] [PubMed]

53. Brunt, E.M. Nonalcoholic steatohepatitis. Semin. Liver Dis. 2004, 24, 3-20. [CrossRef] [PubMed]

54. Diehl, D.L. Endoscopic Ultrasound-guided Liver Biopsy. Gastrointest. Endosc. Clin. N. Am. 2019, 29, $173-186$. [CrossRef] [PubMed]

55. Bazerbachi, F.; Vargas, E.J.; Matar, R.; Storm, A.C.; Mounajjed, T.M.; Topazian, M.D.; Levy, M.J.; Chandrasekhara, V.; Abu Dayyeh, B.K. EUS-guided core liver biopsy sampling using a 22-gauge fork-tip needle: A prospective blinded trial for histologic and lipidomic evaluation in nonalcoholic fatty liver disease. Gastrointest. Endosc. 2019, 90, 926-932. [CrossRef] [PubMed]

56. Saab, S.; Phan, J.; Jimenez, M.A.; Grotts, J.F.; Walters, L.; Hathaway, K.A.; Patel, K.R.; Lankarani, A.; Herman, M.; Holloman, D.A.; et al. Endoscopic Ultrasound Liver Biopsies Accurately Predict the Presence of Fibrosis in Patients With Fatty liver. Clin. Gastroenterol. Hepatol. 2017, 15, 1477-1478. [CrossRef]

57. Shah, N.D.; Sasatomi, E.; Baron, T.H. Endoscopic Ultrasound-guided Parenchymal Liver Biopsy: Single Center Experience of a New Dedicated Core Needle. Clin. Gastroenterol. Hepatol. 2017, 15, 784-786. [CrossRef]

58. Diehl, D.L.; Johal, A.S.; Khara, H.S.; Stavropoulos, S.N.; Al-Haddad, M.; Ramesh, J.; Varadarajulu, S.; Aslanian, H.; Gordon, S.R.; Shieh, F.K.; et al. Endoscopic ultrasound-guided liver biopsy: A multicenter experience. Endosc. Int. Open 2015, 3, E210-E215. [CrossRef]

59. Gor, N.; Salem, S.B.; Jakate, S.; Patel, R.; Shah, N.; Patil, A. Histological adequacy of EUS-guided liver biopsy when using a 19-gauge non-Tru-Cut FNA needle. Gastrointest. Endosc. 2014, 79, 170-172. [CrossRef]

60. Nieto, J.; Khaleel, H.; Challita, Y.; Jimenez, M.; Baron, T.H.; Walters, L.; Hathaway, K.; Patel, K.; Lankarani, A.; Herman, M.; et al. EUS-guided fine-needle core liver biopsy sampling using a novel 19-gauge needle with modified 1-pass, 1 actuation wet suction technique. Gastrointest. Endosc. 2018, 87, 469-475. [CrossRef]

61. Gleeson, F.C.; Clayton, A.C.; Zhang, L.; Clain, J.E.; Gores, G.J.; Rajan, E.; Smyrk, T.C.; Topazian, M.D.; Wang, K.K.; Wiersema, M.J.; et al. Adequacy of endoscopic ultrasound core needle biopsy specimen of nonmalignant hepatic parenchymal disease. Clin. Gastroenterol. Hepatol. 2008, 6, 1437-1440. [CrossRef]

62. Dewitt, J.; McGreevy, K.; Cummings, O.; Sherman, S.; Leblanc, J.K.; McHenry, L.; Al-Haddad, M.; Chalasani, N. Initial experience with EUS-guided Tru-cut biopsy of benign liver disease. Gastrointest. Endosc. 2009, 69, 535-542. [CrossRef]

63. Nakai, Y.; Samarasena, J.B.; Iwashita, T.; Park, D.H.; Lee, J.G.; Hu, K.Q.; Chang, K.J. Autoimmune hepatitis diagnosed by endoscopic ultrasound-guided liver biopsy using a new 19-gauge histology needle. Endoscopy 2012, 44 (Suppl. 2 UCTN), E67-E68. [CrossRef]

64. Sey, M.S.; Al-Haddad, M.; Imperiale, T.F.; McGreevy, K.; Lin, J.; DeWitt, J.M. EUS-guided liver biopsy for parenchymal disease: A comparison of diagnostic yield between two core biopsy needles. Gastrointest. Endosc. 2016, 83, 347-352. [CrossRef]

65. Hasan, M.K.; Kadkhodayan, K.; Idrisov, E.; Ali, S.; Rafiq, E.; Ben-Ami Shor, D.; Abdel-Jalil, A.; Navaneethan, U.; Bang, J.; Varadarajulu, S.; et al. Endoscopic ultrasound-guided liver biopsy using a 22-G fine needle biopsy needle: A prospective study. Endoscopy 2019, 51, 818-824. [CrossRef] [PubMed] 
66. tenBerge, J.; Hoffman, B.J.; Hawes, R.H.; Van Enckevort, C.; Giovannini, M.; Erickson, R.A.; Catalano, M.F.; Fogel, R.; Mallery, S.; Faigel, D.O.; et al. EUS-guided fine needle aspiration of the liver: Indications, yield, and safety based on an international survey of 167 cases. Gastrointest. Endosc. 2002, 55, 859-862. [CrossRef]

67. Chon, H.K.; Yang, H.C.; Choi, K.H.; Kim, T.H. Endoscopic Ultrasound-Guided Liver Biopsy Using a Core Needle for Hepatic Solid Mass. Clin. Endosc. 2019, 52, 340-346. [CrossRef]

68. Ichim, V.A.; Chira, R.I.; Mircea, P.A. Diagnostic yield of endoscopic ultrasound-guided biopsy of focal liver lesions. Med. Pharm. Rep. 2019, 92, 15-20. [CrossRef]

69. Nguyen, P.; Feng, J.C.; Chang, K.J. Endoscopic ultrasound (EUS) and EUS-guided fine-needle aspiration (FNA) of liver lesions. Gastrointest. Endosc. 1999, 50, 357-361. [CrossRef]

70. DeWitt, J.; LeBlanc, J.; McHenry, L.; Ciaccia, D.; Imperiale, T.; Chappo, J.; Cramer, H.; McGreevy, K.; Chriswell, M.; Sherman, S. Endoscopic ultrasound-guided fine needle aspiration cytology of solid liver lesions: A large single-center experience. Am. J. Gastroenterol. 2003, 98, 1976-1981. [CrossRef]

71. McGrath, K.; Brody, D.; Luketich, J.; Khalid, A. Detection of unsuspected left hepatic lobe metastases during EUS staging of cancer of the esophagus and cardia. Am. J. Gastroenterol. 2006, 101, 1742-1746. [CrossRef]

72. Lee, Y.N.; Moon, J.H.; Kim, H.K.; Choi, H.J.; Choi, M.H.; Kim, D.C.; Lee, T.H.; Lee, T.H.; Cha, S.W.; Kim, S.G.; et al. Usefulness of endoscopic ultrasound-guided sampling using core biopsy needle as a percutaneous biopsy rescue for diagnosis of solid liver mass: Combined histological-cytological analysis. J. Gastroenterol. Hepatol. 2015, 30, 1161-1166. [CrossRef]

73. Oh, D.; Seo, D.W.; Hong, S.M.; Song, T.J.; Park, D.H.; Lee, S.S.; Lee, S.K.; Kim, M.H. Endoscopic ultrasound-guided fine-needle aspiration can target right liver mass. Endosc. Ultrasound 2017, 6, 109-115. [CrossRef]

(C) 2020 by the authors. Licensee MDPI, Basel, Switzerland. This article is an open access article distributed under the terms and conditions of the Creative Commons Attribution (CC BY) license (http://creativecommons.org/licenses/by/4.0/). 